\title{
Synthesis and Structure-Activity Relationships of $\mathrm{N}$-Benzyl Phenethylamines as 5- $\mathrm{HT}_{2 \mathrm{~A} / 2 \mathrm{C}}$ Agonists
}

\author{
Martin Hansen, Karina Phonekeo, James S. Paine, Sebastian Leth-Petersen, Mikael Begtrup, \\ Hans Bräuner-Osborne, and Jesper L. Kristensen* \\ Department of Drug Design and Pharmacology, Faculty of Health and Medical Sciences, University of Copenhagen, \\ Universitetsparken 2, 2100 København Ø, Denmark
}

Supporting Information

\begin{abstract}
N$-Benzyl substitution of $5-\mathrm{HT}_{2 \mathrm{~A}}$ receptor agonists of the phenethylamine structural class of psychedelics (such as 4bromo-2,5-dimethoxyphenethylamine, often referred to as 2C-B) confer a significant increase in binding affinity as well as functional activity of the receptor. We have prepared a series of 48 compounds with structural variations in both the phenethylamine and $\mathrm{N}$-benzyl part of the molecule to determine the effects on receptor binding affinity and functional activity at $5-\mathrm{HT}_{2 \mathrm{~A}}$ and

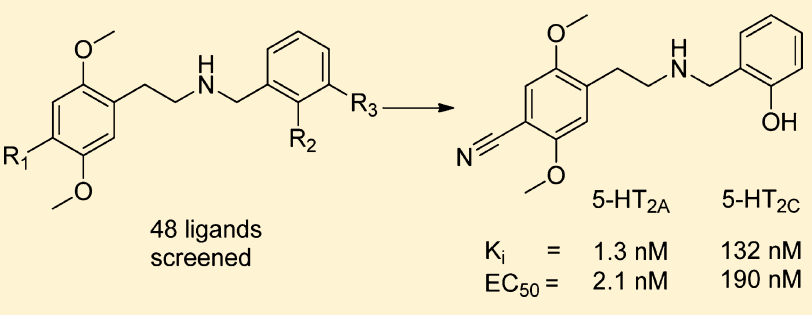
$5-\mathrm{HT}_{2 \mathrm{C}}$ receptors. The compounds generally had high affinity for the $5-\mathrm{HT}_{2 \mathrm{~A}}$ receptor with $\mathbf{8 b}$ having the highest affinity at $0.29 \mathrm{nM}$ but with several other compounds also exhibiting subnanomolar binding affinities. The functional activity of the compounds was distributed over a wider range with $\mathbf{1 b}$ being the most potent at $0.074 \mathrm{nM}$. Most of the compounds exhibited low to moderate selectivity (1- to 40 -fold) for the 5 - $\mathrm{HT}_{2 \mathrm{~A}}$ receptor in the binding assays, although one compound $\mathbf{6 b}$ showed an impressive 100 -fold selectivity for the 5-HT $2 \mathrm{~A}$ receptor. In the functional assay, selectivity was generally higher with $\mathbf{1 b}$ being more than 400 -fold selective for the $5-\mathrm{HT}_{2 \mathrm{~A}}$ receptor.
\end{abstract}

KEYWORDS: Serotonin, 5-HT $\mathrm{HA}_{2 \mathrm{~A}}$ receptor agonist, $\mathrm{N}$-benzyl phenethylamines, selectivity

S erotonin (5-HT) receptors are widely distributed in both the CNS and the peripheral nervous system and are involved in the regulation of a plethora of physiological responses such as cognition, memory processing, mood, circadian behavior, and appetite. ${ }^{1}$ The $5-\mathrm{HT}_{2 \mathrm{~A}}$ receptor appears to play a key role in a number of disease states such as addiction, ${ }^{2}$ schizophrenia, ${ }^{3}$ obsessive compulsive disorder, ${ }^{4,5}$ depression, ${ }^{6,7}$ pain, ${ }^{8}$ inflammation, ${ }^{9}$ migraine, ${ }^{10}$ and cluster headaches, ${ }^{11}$ and in the manifestation of mystical/religious-type experiences as well as in altered states of consciousness. ${ }^{3,12-15}$ Agonist activation of 5- $\mathrm{HT}_{2 \mathrm{~A}}$ receptors in the cortex is believed to be responsible for the remarkable psychopharmacological effects exerted by hallucinogens such as lysergic acid diethylamide (LSD) and psilocybin; see Figure $1 .{ }^{16}$ Neutral antagonists such as 2-bromolysergic acid diethylamide (BOL-

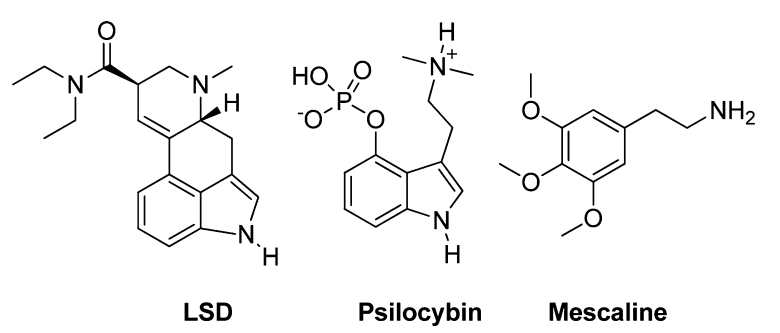

Figure 1. Representative members of the three structural groups of 5$\mathrm{HT}_{2 \mathrm{~A}}$ agonists. LSD (an ergoline), psilocybin (a tryptamine), and mescaline (a phenethylamine).
148) have been investigated as a prophylactic treatment of cluster headaches, and inverse agonists such as risperidone and clozapine are well-known atypical antipsychotics. ${ }^{17,18}$

5- $\mathrm{HT}_{2 \mathrm{~A}}$ agonists have traditionally been divided into three structural groups: Ergolines, tryptamines, and phenethylamines. ${ }^{19}$ The ergoline group is named after the ergot fungus which was the initial source of ergot alkaloids, but ergolines are also known to occur naturally in several other species of plant and fungi. ${ }^{20}$ The ergolines comprise a varied group of compounds with a rich pharmacology and bind to many types of monoamine receptors both serotonergic and nonserotonergic. Not all ergolines are $5-\mathrm{HT}_{2 \mathrm{~A}}$ agonists and several are used clinically in the treatment of migraine, ${ }^{21}$ Parkinson's disease and in obstetrics. ${ }^{2,23}$

Tryptamines are slightly more selective compounds but usually have strong affinity for several 5-HT receptors. Serotonin itself is an agonist at all 5-HT receptors, whereas the classical hallucinogens psilocybin and N,N-dimethyltryptamine (DMT) activate $5-\mathrm{HT}_{1 \mathrm{~A}}$ receptors as well as the $5-\mathrm{HT}_{2}$ subtypes.

Phenethylamines are generally selective for the $5-\mathrm{HT}_{2}$ receptor subtypes but lack selectivity between the individual subtypes. $^{24}$ The optimal substitution pattern and molecular configuration for simple phenethylamines have been refined

Received: December 5, 2013

Revised: January 7, 2014

Published: January 7, 2014 
and improved during the past 40 years and have resulted in some very potent agonists. ${ }^{25,26}$

Initially, $N$-substituted phenethylamines were thought to be inferior compared to the parent phenethylamines because early studies involving $\mathrm{N}$-alkylation with simple substituents (e.g., methyl, ethyl, propyl) produced compounds with significantly diminished activity. ${ }^{27,28}$ Therefore, it was surprising when it was discovered that $N$-benzyl and specifically $N$-(2-methoxy)benzyl substitution dramatically improved both binding affinity and functional activity and in vivo $5-\mathrm{HT}_{2 \mathrm{~A}}$ activation of simple phenethylamines such as 2C-I (4-iodo-2,5-dimethoxyphenethylamine). ${ }^{29,30}$ This discovery was later expanded upon to include conformationally restricted $N$-benzylphenethylamines which resulted in the first truly selective $5-\mathrm{HT}_{2 \mathrm{~A}}$ agonist. ${ }^{31}$

As part of our efforts to develop an agonist PET-tracer for the $5-\mathrm{HT}_{2 \mathrm{~A}}$ receptor, we have examined a number of different $\mathrm{N}$-benzylphenethylamines for their ability to bind to and activate $5-\mathrm{HT}_{2 \mathrm{~A}}$ receptors in the search for a $5-\mathrm{HT}_{2 \mathrm{~A}}$ selective agonist. $^{32}$ Agonists are of special interest in PET studies because agonist PET-ligands only label receptors in the active, high-affinity state which provides more functionally relevant imaging. Furthermore, agonist PET-ligands are potentially more sensitive to changes in synaptic serotonin levels due to the higher affinity of 5-HT for agonist versus antagonist labeled receptors. Several ligands from the study have been investigated as PET-ligands, and 5a (under the alias Cimbi-36) is currently being evaluated in humans. ${ }^{33}$ Herein we wish to report the full details on the medicinal chemistry development of these ligands. We wanted to study the impact of the 4-substituent on $N$-benzylphenethylamines with a small set of $N$-benzyl substituents and determine the effects on both binding affinity and functional activity at the $5-\mathrm{HT}_{2 \mathrm{~A}}$ receptor as well as the 5$\mathrm{HT}_{2 \mathrm{C}}$ receptor. Extensive structure-activity relationship (SAR) studies have previously been performed on the 4-position of psychedelic phenethylamines and amphetamines. ${ }^{27,34}$ These studies revealed that 4-substituents containing hydrogen bond donors such as $-\mathrm{COOH},-\mathrm{OH}$, and $-\mathrm{NH}_{2}$ decrease affinity by several orders of magnitude while nonpolar substituents such as halogens and alkyl groups increased affinity. Thus, there seems to be a clear correlation between the lipophilic nature of the substituent in the 4-position and binding affinity; however, only halogens and short alkyl chains (1-4 carbons) are agonists while longer alkyl chains, aryl and benzyl groups are antagonists at the $5-\mathrm{HT}_{2 \mathrm{~A}}$ receptor.

Herein we report our efforts to investigate the SAR of this compound family via a systematic variation of substituents on the phenethylamine and benzyl rings. Twelve phenethylamines were paired with 4 benzaldehydes to give a set of $48 \mathrm{~N}$-benzyl phenethylamines that subsequently were evaluated on the 5$\mathrm{HT}_{2 \mathrm{~A}}$ and $5-\mathrm{HT}_{2 \mathrm{C}}$ receptors in binding and functional assays.

\section{CHEMISTRY}

The targeted 48 compounds were all synthesized by indirect reductive amination of the respective phenethylamines and benzaldehydes as shown in Scheme 1. The N-benzylphenethylamines were precipitated as their hydrochloride salts in 46$94 \%$ isolated yields. The syntheses of the parent 12 phenethylamines have been described previously; see the Supporting Information for details.
Scheme 1. Synthesis of $N$-Benzyl Phenethylamines ${ }^{a}$

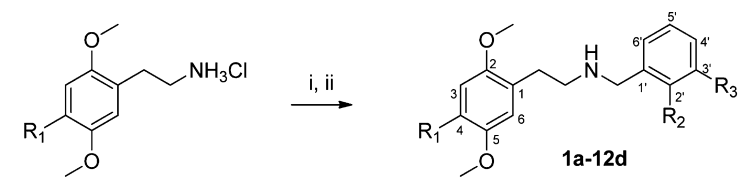

\begin{tabular}{|c|c|c|c|c|c|c|c|c|c|c|c|c|}
\hline$\underline{R_{2} / R_{3} \backslash R_{1}}$ & 1 & $\mathrm{Br}$ & $\mathrm{Cl}$ & $\mathrm{F}$ & $\mathrm{CF}_{3}$ & $\mathrm{CN}$ & $\mathrm{Me}$ & $\mathrm{Et}$ & $\mathrm{Pr}$ & SMe & SEt & $\mathrm{SPr}$ \\
\hline 2'-MeO & $1 a$ & $2 a$ & $3 a$ & $4 d$ & $5 a$ & $6 a$ & $7 a$ & $8 a$ & $9 a$ & $10 a$ & $11 a$ & $12 a$ \\
\hline 2'-OH & $1 b$ & $2 b$ & $3 b$ & $4 b$ & $5 b$ & $6 b$ & $7 b$ & $8 b$ & $9 b$ & $10 \mathrm{~b}$ & $11 \mathrm{~b}$ & $12 b$ \\
\hline $2 '-F$ & 1c & 2c & $3 c$ & $4 c$ & $5 c$ & $6 c$ & 7c & $8 c$ & $9 c$ & $10 c$ & $11 \mathrm{c}$ & $12 c$ \\
\hline 2',3'-MD & 1d & $2 d$ & 3d & 4d & $5 d$ & $6 d$ & $7 d$ & $8 d$ & $9 d$ & $10 \mathrm{~d}$ & 11d & $12 d$ \\
\hline
\end{tabular}

${ }^{a}$ Reaction conditions: (i) aldehyde, EtOH, rt; (ii) $\mathrm{NaBH}_{4}$, EtOH, rt.

\section{IN VITRO PHARMACOLOGY}

All compounds were assessed in a radioligand competition binding assay for affinity at human $5-\mathrm{HT}_{2 \mathrm{~A}}$ receptors and rat 5$\mathrm{HT}_{2 \mathrm{C}}$ receptors using displacement of antagonist radioligands $\left[{ }^{3} \mathrm{H}\right]$ Ketanserin and $\left[{ }^{3} \mathrm{H}\right]$ Mesulergine via the NIMH Psychoactive Drug Screening Program (PDSP). The results are summarized in Figure 2. In Figure 3, the 5- $\mathrm{HT}_{2 \mathrm{~A} / 2 \mathrm{C}}$ selectivities based on the data in Figure 2 are presented.

Functional assays were performed on all compounds to determine the ability of the ligands to activate downstream cellular signaling pathways. The compounds were examined for their efficacy at stimulating phospholipase $\mathrm{C}$ mediated production of inositol phosphates $\left(\mathrm{IP}_{1-3}\right)$ at both human 5$\mathrm{HT}_{2 \mathrm{~A}}$ and $5-\mathrm{HT}_{2 \mathrm{C}}$ receptors. The results are summarized in Figure 4; see the Supporting Information for full details.

\section{RESULTS AND DISCUSSION}

The results from the binding affinity measurements showed that the majority of the compounds bind to both 5- $\mathrm{HT}_{2 \mathrm{~A}}$ and 5$\mathrm{HT}_{2 \mathrm{C}}$ receptors in the low nanomolar range with several compounds having subnanomolar affinities $\left(\mathrm{p} K_{\mathrm{i}}\right.$ above 9$)$ at the $5-\mathrm{HT}_{2 \mathrm{~A}}$ receptor. Previously, a smaller subset of compounds were subjected to a broader screen which showed the $\mathrm{N}$-benzyl phenethylamines are highly selective for the $5-\mathrm{HT}_{2}$ receptor subtypes over a wide selection of other neuroreceptors. ${ }^{32}$ Ligands substituted with $\mathrm{F}, \mathrm{CN}$, or $\mathrm{Me}$ at the 4-position of the phenethylamine core $(4 a-d, 6 a-d$, and $7 a-d)$ have slightly lower affinities which is in accordance with affinity data published previously on simple/primary phenethylamines and amphetamines. $^{35}$ In general, the ligands with a $\mathrm{N}$-(2fluorobenzyl) substituent $(\mathbf{1 c}-\mathbf{1 2 c})$ have lower affinities than the other $N$-benzyl substituents which could be due to a diminished hydrogen bond acceptor capability.

While all compounds were generally $5-\mathrm{HT}_{2 \mathrm{~A}}$-selective in the binding assays, the selectivity varied with the nature of both the 4-substituents and the $N$-benzyl substituents. 2,3-Methylenedioxy substitution on the $N$-benzyl part results in a general increase in the $5-\mathrm{HT}_{2 \mathrm{~A}}$-selective binding with most 4substituents; see Figure 3. The influence of the other N-benzyl substituents on $5-\mathrm{HT}_{2 \mathrm{~A} / 2 \mathrm{C}}$-selectivity was too erratic to show any general trends. The same applies to the 4-substituents which do not display any general trends. In Figure 5, 5b, 5d, 6b, and $\mathbf{6} \mathbf{d}$ are shown for comparison. Compound $\mathbf{5 b}$ is a very potent agonist with 85-fold selectivity in the functional assays, but low selectivity (3-fold) in the binding assay. In $\mathbf{5 d}$, the methylenedioxy moiety in the $\mathrm{N}$-benzyl group increases the selectivity to a factor of 226 and 18, respectively, while maintaining potency. Exchanging the $\mathrm{CF}_{3}$-group for a $\mathrm{CN}$ - 

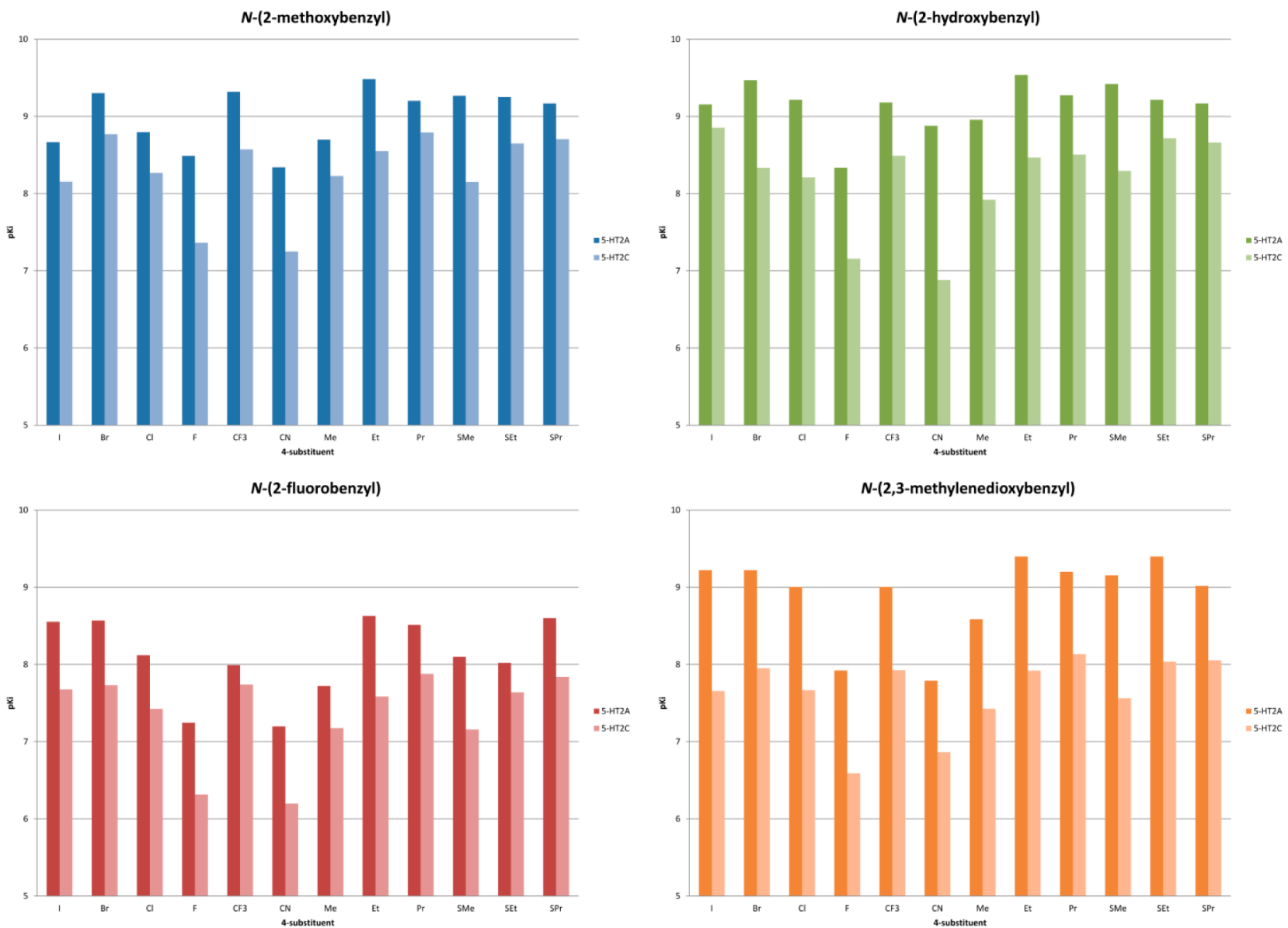

Figure 2. Binding affinities $\left(\mathrm{p} K_{\mathrm{i}}\right)$ of $\mathrm{N}$-benzylphenethylamines at the $5-\mathrm{HT}_{2 \mathrm{~A}}$ and $5-\mathrm{HT}_{2 \mathrm{C}}$ receptor. See the Supporting Information for tables with all data.

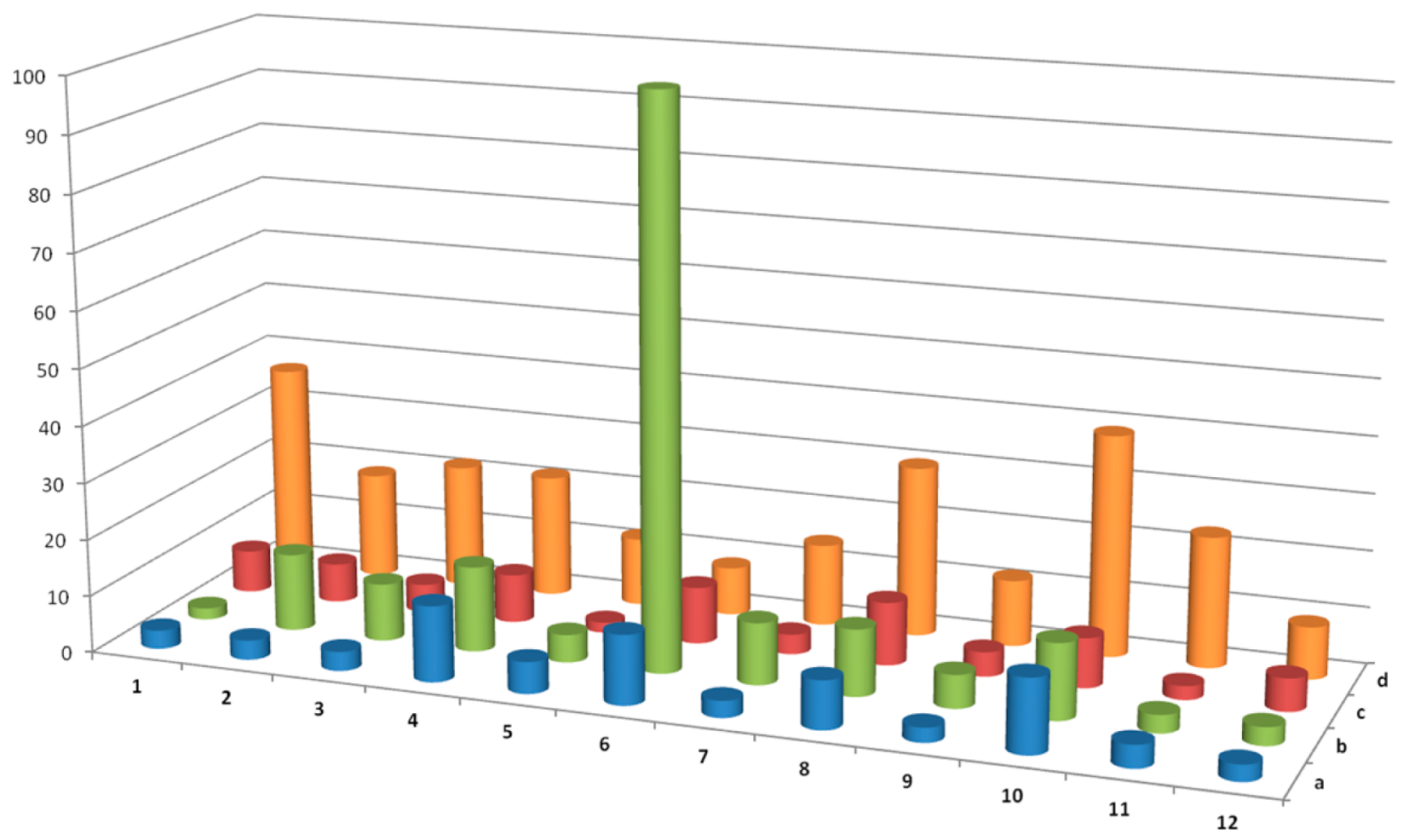

Figure 3. Graph showing the $5-\mathrm{HT}_{2 \mathrm{~A}} / 5-\mathrm{HT}_{2 \mathrm{C}}$ selectivities based on binding affinities. 

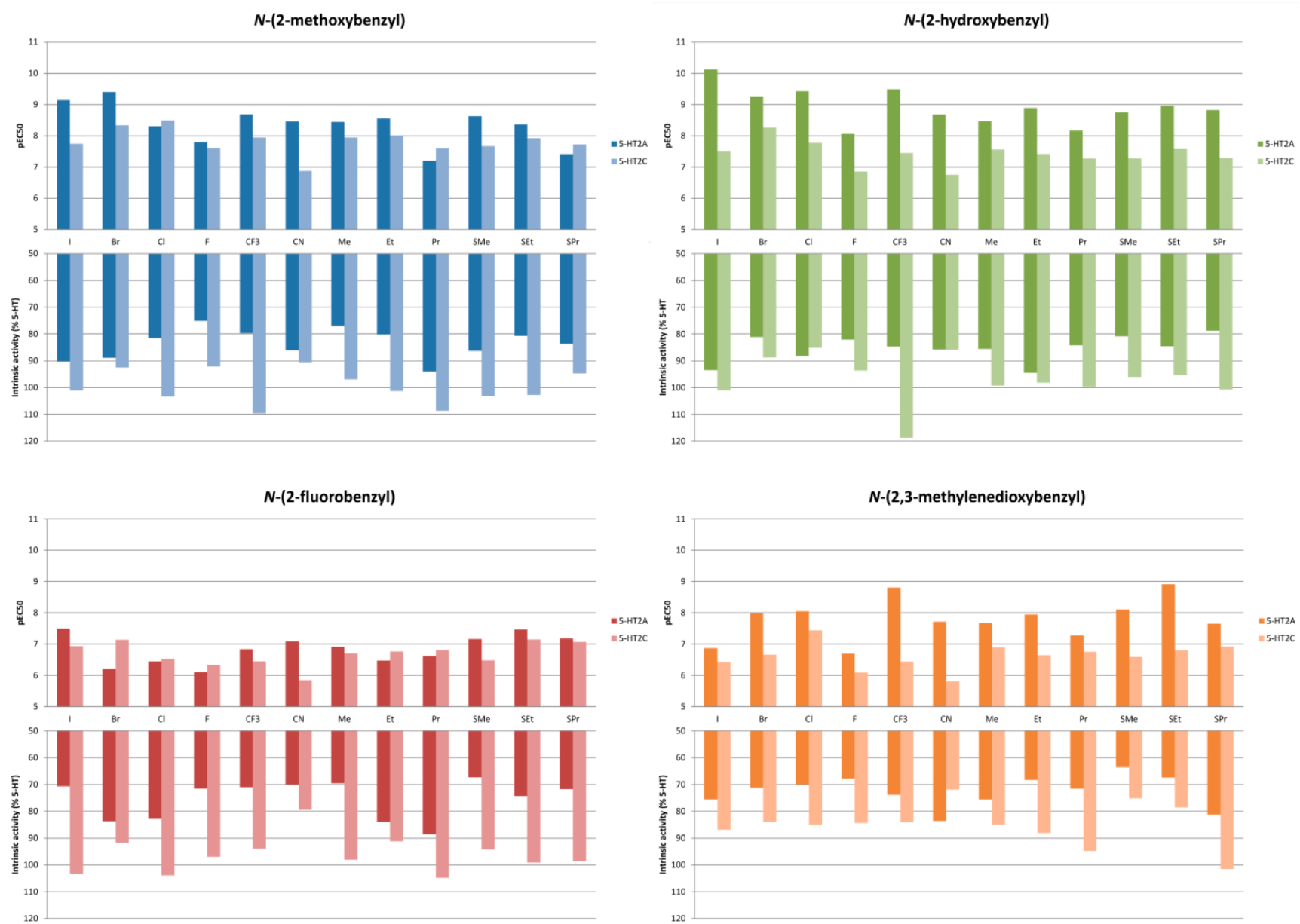

Figure 4. Functional characterization of $N$-benzylphenethylamines at human 5- $\mathrm{HT}_{2 \mathrm{~A}}$ and $5-\mathrm{HT}_{2 \mathrm{C}}$ receptors. Top half shows $\mathrm{pEC} \mathrm{C}_{50}$, whereas bottom half represents intrinsic activity.
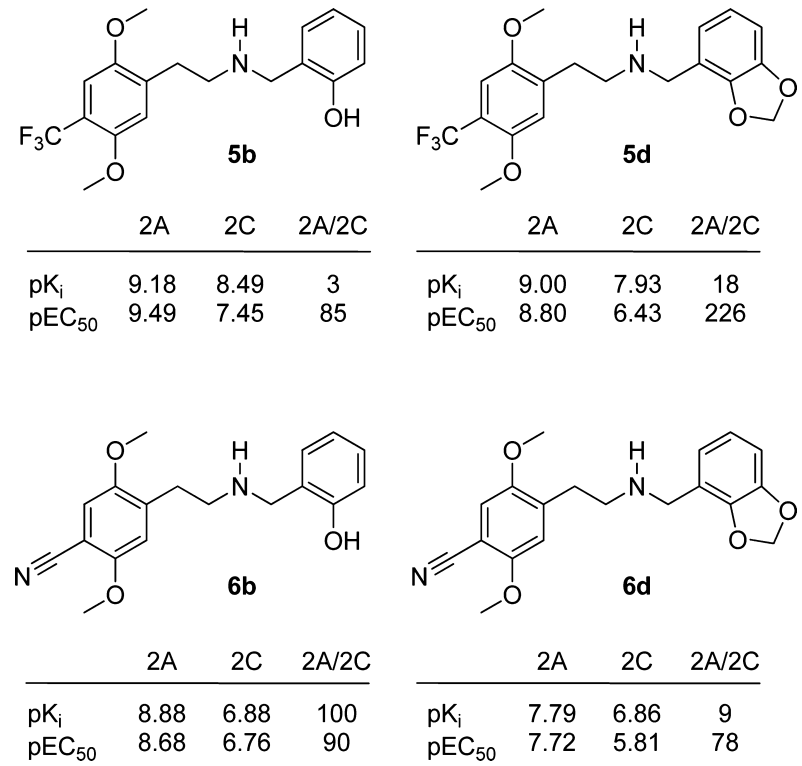

Figure 5. Structure and in vitro pharmacological profile of $\mathbf{5 b}, \mathbf{5 d}, \mathbf{6 b}$, and $6 \mathrm{~d}$.

group in these two compounds gives two very different results: $\mathbf{6 b}$ retains the high affinity for $5-\mathrm{HT}_{2 \mathrm{~A}}$, while affinity for $5-\mathrm{HT}_{2 \mathrm{C}}$ diminishes, giving a 100-fold selective compound, whereas in 6d the same $\mathrm{CF}_{3}$ to $\mathrm{CN}$ substitution leads to an erosion of both affinity and selectivity for $5-\mathrm{HT}_{2 \mathrm{~A}}$. In Figure 6, the concentration-response curves for $\mathbf{6 b}$ and $\mathbf{6} \mathbf{d}$ on $5-\mathrm{HT}_{2 \mathrm{~A}}$ and $5-\mathrm{HT}_{2 \mathrm{C}}$ are compared with DOI. As can be seen in Figure 3, the combination of the 4-CN and $N$-(2-hydroxybenzyl) substituents in $\mathbf{6} \mathbf{b}$ gives the most selective compound in the series with respect to binding affinities. In simple amphetamines with the same substitution pattern, the 4-CN substitution results in a moderate (20-fold) selectivity toward $5-\mathrm{HT}_{2 \mathrm{~A}}$ and it appears that this property is augmented by the $2^{\prime}$-hydroxybenzyl substituent but not by the other $N$-benzyl groups examined in this study. Attempts to rationalize the structure-activity relationships via docking of the ligand set in previously reported $5-\mathrm{HT}_{2 \mathrm{~A} / 2 \mathrm{C}}$ homology-models were unsuccessful. ${ }^{35}$

In the functional assay, the $\mathrm{N}$-(2-hydroxybenzyl) substituted compounds generally showed the highest activity at the 5- $\mathrm{HT}_{2 \mathrm{~A}}$ receptor with moderate to good selectivity. With very few exceptions, the intrinsic activity was above $70 \%$ for all compounds on both 5- $\mathrm{HT}_{2 \mathrm{~A}}$ and 5- $\mathrm{HT}_{2 \mathrm{C}} \cdot \mathrm{N}$-(2-Methoxybenzyl) compounds $(1-12 a)$ were less active and also less selective $5-\mathrm{HT}_{2 \mathrm{~A}}$ agonists. From the $\mathrm{N}$-(2-hydroxybenzyl) compounds, $\mathbf{1 b}$ emerged as the most functionally potent of all ligands tested with an $\mathrm{EC}_{50}$ of $0.074 \mathrm{nM}$ with more than 400 -fold selectivity for the $5-\mathrm{HT}_{2 \mathrm{~A}}$ receptor. The $\mathrm{N}$-(2,3-methylenedioxybenzyl) substituted compounds $(\mathbf{1 d - 1 2 d})$ were generally less potent. The $N$-(2-fluorobenzyl) compounds $(1 \mathbf{c}-12 c)$ were inferior in terms of affinity, efficacy, and selectivity compared to the other 
A

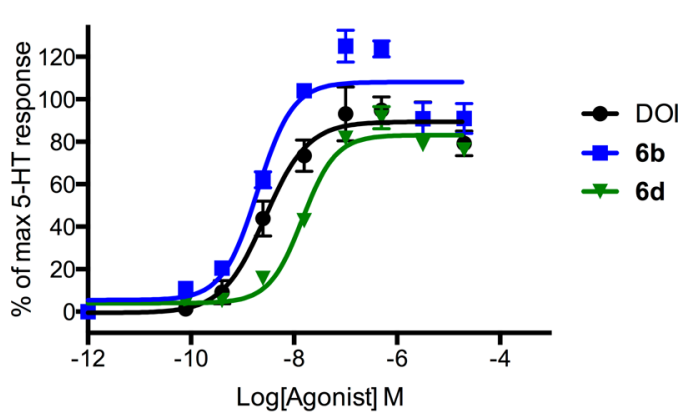

B $5-\mathrm{HT}_{2 \mathrm{C}}$

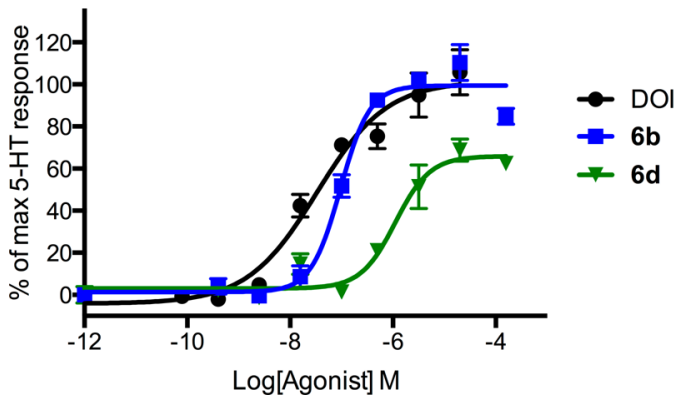

Figure 6. Concentration-response curves of the agonists DOI, $\mathbf{6 b}$ and 6d at $5-\mathrm{HT}_{2 \mathrm{~A}}(\mathrm{~A})$ and $5-\mathrm{HT}_{2 \mathrm{C}}$ (B) receptors, respectively. Concentration-response curves were generated from stimulation of inositol phosphate formation in tsA cells transiently expressing either $5-\mathrm{HT}_{2 \mathrm{~A}}$ (A) or $5-\mathrm{HT}_{2 \mathrm{C}}$ (B) receptors. The formation of inositol phosphate was determined as described in Methods and calculated as percent response compared to a full 5-HT response. Data shown are mean $\pm S D$ of a single representative experiment performed in triplicate. Two additional experiments gave similar results.

three series, mirroring the results from the binding assays, but comparable to the parent phenethylamines.

In simple phenethylamines, the functional activity drops as the size of the 4-substituent is increased. This is mirrored in our result: Starting from 4-methyl $(\mathbf{7 b})$, there is a drop in activity going from ethyl (8b) to propyl (9b) with the $\mathrm{N}$-(2hydroxybenzyl) substituent. In the $N$-(2,3-methylendioxybenzyl) series, the trend is similar; in the 4-thioalkyl series, 10d11d-12, where 11d is the most potent of the three; see Figure 7. Thus, it appears that the substituent on the $N$-benzyl somehow influences the interaction of the 4-substituent as well.

In conclusion, we have investigated the structure activity relationship of 48 closely related $N$-benzyl phenethylamines as $5-\mathrm{HT}_{2 \mathrm{~A} / 2 \mathrm{C}}$ agonists. From that study, several interesting

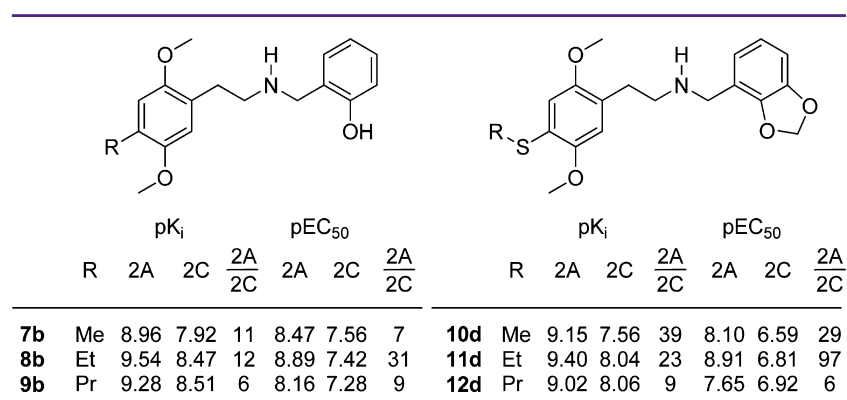

Figure 7. Structure and in vitro pharmacological profile of $7 \mathbf{b}-9 \mathbf{b}$ and $10 \mathrm{~d}-12 \mathrm{~d}$. compounds emerged. Several compounds displayed affinities and potencies in the picomolar range with varying levels of selectivity. Although the structure activity relations of the 48 ligands were erratic, the effect of the cyano substituent in the 4position and the general trend of the $N$-(2,3-methylenedioxybenzyl) substituted phenethylamines on the selectivity is an interesting new observation. The most selective compound (when taking both binding and functional data into account) was 6 b being 100- and 90-fold selective; see Figure 8. In 2013,

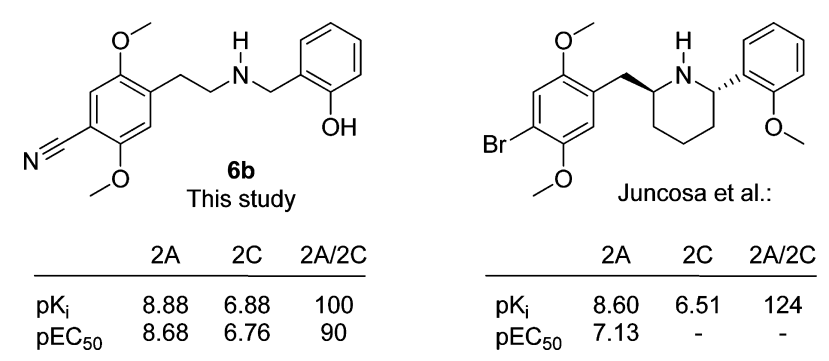

Figure 8. Comparison between $\mathbf{5 d}$ and $5-\mathrm{HT}_{2 \mathrm{~A}}$ selective agonist published by Juncosa et al. in 2013.

Juncosa et al. ${ }^{31}$ published a conformationally restrained $N$ benzyl phenethylamine with more than 100 -fold selectivity for the $5-\mathrm{HT}_{2 \mathrm{~A}}$ receptor; see Figure 8 . We are currently pursuing ligands where these structural motifs are merged in the search for even more selective $5-\mathrm{HT}_{2 \mathrm{~A}}$ agonists.

\section{METHODS}

Synthesis of Secondary Amines. $\mathrm{Et}_{3} \mathrm{~N}$ (1.0 equiv) was added to a suspension of the phenethylamine hydrochloride $(1.0 \mathrm{mmol})$ and aldehyde (1.1 equiv) in $\mathrm{EtOH}(10 \mathrm{~mL})$, and the reaction was stirred until formation of the imine was complete according to TLC or GC $(30 \mathrm{~min}$ to $3 \mathrm{~h}) . \mathrm{NaBH}_{4}(2.0 \mathrm{mmol})$ was added, and the reaction was stirred for another $30 \mathrm{~min}$. The reaction mixture was concentrated under reduced pressure and partitioned between $\mathrm{CH}_{2} \mathrm{Cl}_{2} / \mathrm{H}_{2} \mathrm{O}$ (30 $\mathrm{mL}, 1: 1)$. The organic layer was isolated, and the aqueous layer was extracted with $\mathrm{CH}_{2} \mathrm{Cl}_{2}(2 \times 15 \mathrm{~mL})$. The combined organic extracts were dried $\left(\mathrm{Na}_{2} \mathrm{SO}_{4}\right)$, filtered, and evaporated under reduced pressure. The residue was purified by flash chromatography $\left(\mathrm{CH}_{2} \mathrm{Cl}_{2} / \mathrm{MeOH} /\right.$ $\mathrm{NH}_{3}$ 98:2:0.04). The purified free base was dissolved in EtOH $(2 \mathrm{~mL})$, there was added ethanolic $\mathrm{HCl}(1 \mathrm{M}, 2 \mathrm{~mL})$, and the solution was diluted with $\mathrm{Et}_{2} \mathrm{O}$ until crystals formed. The crystals were collected by filtration and dried under reduced pressure.

Functional Pharmacology. Cell culturing, transfection, and inositol phosphate turnover assay were adopted from a previously published procedure. ${ }^{36}$

Cell Culture and Transfections. tsA201 cells (a transformed HEK293 cell line) were cultured in GlutaMAX-I Dulbecco's modified Eagle's medium (DMEM) supplemented with $10 \%$ dialyzed fetal bovine serum, penicillin $\left(100 \mathrm{U} \mathrm{mL}^{-1}\right)$, and streptomycin $(100 \mathrm{mg}$ $\left.\mathrm{mL}^{-1}\right)$ at $37{ }^{\circ} \mathrm{C}$ in a humidified atmosphere of $95 \%$ air and $5 \% \mathrm{CO}_{2}$. Constructs encoding human $5-\mathrm{HT}_{2 \mathrm{~A}}$ and $5-\mathrm{HT}_{2 \mathrm{C}}$ in pcDNA3.1 were obtained from the Missouri S\&T cDNA Resource Center (www.cdna. org) and transiently transfected into cells using PolyFect according to the manufacturer's protocol (Qiagen, West Sussex, U.K.).

Inositol Phosphate (IP) Turnover Assay. The day after transfection, tsA201 cells were split into poly-D-lysine-coated 96-well tissue culture plates in inositol-free DMEM supplemented with $10 \%$ dialyzed fetal bovine serum, penicillin $\left(100 \mathrm{U} \mathrm{mL}^{-1}\right)$, streptomycin $\left(100 \mathrm{mg} \mathrm{mL}^{-1}\right.$ ), and $4 \mu \mathrm{Ci} \mathrm{mL}{ }^{-1} m y o-\left[2-{ }^{3} \mathrm{H}\right]$ inositol (GE Healthcare, Buckinghamshire, U.K.). Two days after transfection, cells were washed with assay buffer 1 (Hanks' balanced saline solution (HBSS) containing $20 \mathrm{mM}$ HEPES, $1 \mathrm{mM} \mathrm{CaCl}, 1 \mathrm{mM} \mathrm{MgCl}_{2}$, and $1 \mathrm{mg}$ $\mathrm{mL}^{-1}$ BSA, $\mathrm{pH}$ 7.4) and preincubated in $100 \mu \mathrm{L}$ assay buffer 1 for $4 \mathrm{~h}$ at $37^{\circ} \mathrm{C}$, where the buffer was replaced after $2 \mathrm{~h}$. The cells were then 
washed and subsequently incubated in $50 \mu \mathrm{L}$ of assay buffer 2 (HBSS containing $1 \mathrm{mM} \mathrm{CaCl}_{2}, 1 \mathrm{mM} \mathrm{MgCl}$, and $20 \mathrm{mM} \mathrm{LiCl}$ ) for $30 \mathrm{~min}$ at $37^{\circ} \mathrm{C}$. Following this incubation, the cells were stimulated with 50 $\mu \mathrm{L}$ of the indicated agonists in assay buffer 2 for $30 \mathrm{~min}$ at $37^{\circ} \mathrm{C}$.

The reactions were stopped by exchanging the buffer with $50 \mu \mathrm{L}$ ice-cold $10 \mathrm{mM}$ formic acid and incubating the cells at $4{ }^{\circ} \mathrm{C}$ for at least $30 \mathrm{~min}$. Yttrium silicate scintillation proximity assay beads (GE Healthcare, Buckinghamshire, U.K.) were used for measuring radioactivity from generated $\left[{ }^{3} \mathrm{H}\right]$-IP essentially as previously described. ${ }^{37}$ In brief, $20 \mu \mathrm{L}$ of the formic acid cell extracts were transferred to white 96-well plates, and $1 \mathrm{mg}$ of yttrium silicate scintillation proximity assay beads suspended in $80 \mu \mathrm{L}$ water added to each well. The plates were sealed, shaken vigorously for $1 \mathrm{~h}$, and centrifuged at $1500 \mathrm{rpm}$ for $5 \mathrm{~min}$. The radioactivity was quantified in a Wallac Microbeta scintillation counter, and responses read as counts per minute (CPM). All experiments were performed in triplicate and repeated in at least three independent experiments.

\section{ASSOCIATED CONTENT}

\section{S Supporting Information}

NMR-data, including copies of ${ }^{1} \mathrm{H}$ and ${ }^{13} \mathrm{C}$ NMR spectra and full details on the pharmacological characterization. This material is available free of charge via the Internet at http:// pubs.acs.org.

\section{AUTHOR INFORMATION}

\section{Corresponding Author}

*Phone: +45 3533 6487. E-mail: jesper.kristensen@sund.ku.dk.

\section{Author Contributions}

J.K., M.H., M.B., and H.B.O. conceived the experiments. M.H. and J.S.P. synthesized the compounds. M.H. and S.L.P. characterized the compounds. K.P. and H.B.O. performed the functional assays. M.H., S.L.P., and J.L.K. prepared the manuscript.

\section{Funding}

The Lundbeck foundation, the Danish Ministry of Science, Innovation, and Higher Education and the The A. P. Møller Foundation for the Advancement of Medical Sciences are gratefully acknowledged for financial support.

\section{Notes}

The authors declare no competing financial interest.

\section{ACKNOWLEDGMENTS}

Radioligand competition binding assay for affinity at human 5$\mathrm{HT}_{2 \mathrm{~A}}$ receptors and rat $5-\mathrm{HT}_{2 \mathrm{C}}$ receptors using displacement of antagonist radioligands $\left[{ }^{3} \mathrm{H}\right]$ Ketanserin and $\left[{ }^{3} \mathrm{H}\right]$ Mesulergine was generously provided by the National Institute of Mental Health's Psychoactive Drug Screening Program, Contract \# HHSN-271-2008-00025-C (NIMH PDSP). The NIMH PDSP is Directed by Bryan L. Roth $\mathrm{MD}, \mathrm{PhD}$ at the University of North Carolina at Chapel Hill and Project Officer Jamie Driscol at NIMH, Bethesda MD.

\section{REFERENCES}

(1) Berger, M., Gray, J. A., and Roth, B. L. (2009) The Expanded Biology of Serotonin. Annu. Rev. Med. 60, 355-366.

(2) Krebs, T. S., and Johansen, P. Ø. (2012) Lysergic acid diethylamide (LSD) for alcoholism: meta-analysis of randomized controlled trials. J. Psychopharmacol. 26 (7), 994-1002.

(3) Vollenweider, F. X., Vollenweider-Scherpenhuyzen, M. F., Babler, A., and Vogel, H. (1998) Psilocybin induces schizophrenia-like psychosis in humans via a serotonin- 2 agonist action. NeuroReport 9 (17), 3897-3902.
(4) Adams, K. H., Hansen, E. S., Pinborg, L. H., Hasselbalch, S. G., Svarer, C., Holm, S., Bolwig, T. G., and Knudsen, G. M. (2005) Patients with obsessive-compulsive disorder have increased $5-\mathrm{HT}_{2 \mathrm{~A}}$ receptor binding in the caudate nuclei. Int. J. Neuropsychopharmacol. 8 (3), 391-401.

(5) Moreno, F. A., Wiegand, C. B., Taitano, E. K., and Delgado, P. L. (2006) Safety, tolerability and efficacy of psilocybin in 9 patients with obsessive compulsive-compulsive disorder. J. Clin. Psychiatry 67 (11), $1735-1740$.

(6) Celada, P., Puig, M. V., Amargós-Bosch, M., Adell, A., and Artigas, F. (2004) The therapeutic role of $5-\mathrm{HT}_{1 \mathrm{~A}}$ and $5-\mathrm{HT}_{2 \mathrm{~A}}$ receptors in depression. J. Psychiatry Neurosci. 29 (4), 252-265.

(7) Carhart-Harris, R. L., Erritzoe, D., Williams, T., Stone, J. M., Reed, L. J., Colasanti, A., Tyacke, R. J., Leech, R., Malizia, A. L., Murphy, K., Hobden, P., Evans, J., Feilding, A., Wise, R. G., and Nutt, D. J. (2012) Neural correlates of the psychedelic state as determined by fMRI studies with psilocybin. Proc. Natl. Acad. Sci. U.S.A. 109 (6), $2138-2143$

(8) Okamoto, K., Imbe, H., Kimura, A., Donishi, T., Tamai, Y., and Senba, E. (2007) Activation of central $5 \mathrm{HT}_{2 \mathrm{~A}}$ receptors reduces the craniofacial nociception of rats. Neuroscience 147 (4), 1090-1102.

(9) Nau, F., Jr., Yu, B., Martin, D., and Nichols, C. D. (2013) Serotonin 5-HT2A Receptor Activation Blocks TNF-a Mediated Inflammation In Vivo. PLoS One 8 (10), e75426.

(10) Hamel, E. (2007) Serotonin and migraine: biology and clinical implications. Cephalalgia 27 (11), 1293-1300.

(11) Sewell, R. A., Halpern, J. H., and Pope, H. G., Jr. (2006) Response of cluster headache to psilocybin and LSD. Neurology 66 (12), 1920-1922.

(12) Griffiths, R. R., Richards, W. A., McCann, U., and Jesse, R. (2006) Psilocybin can occasion mystical-type experiences having substantial and sustained personal meaning and spiritual significance. Psychopharmacology 187 (3), 268-283.

(13) Griffiths, R., Richards, W., Johnson, M., McCann, U., and Jesse, R. (2008) Mystical-type experiences occasioned by psilocybin mediate the attribution of personal meaning and spiritual significance 14 months later. J. Psychopharmacol. 22 (6), 621-632.

(14) Griffiths, R. R., Johnson, M. W., Richards, W. A., Richards, B. D., McCann, U., and Jesse, R. (2011) Psilocybin occasioned mystical-type experiences: immediate and persisting dose-related effects. Psychopharmacology 218, 649-665.

(15) Vollenweider, F. X., and Geyer, M. A. (2001) A systems model of altered consciousness: integrating natural and drug-induced psychoses. Brain Res. Bull. 56 (5), 495-507.

(16) Nichols, D. E. (2004) Hallucinogens. Pharmacol. Ther. 2, 13181.

(17) Karst, M., Halpern, J. H., Bernateck, M., and Passie, T. (2010) The non-hallucinogen 2-bromo-lysergic acid diethylamide as preventative treatment for cluster headache: an open, non-randomized case series. Cephalalgia 30 (9), 1140-1144.

(18) Weiner, D. M., Burstein, E. S., Nash, N., Croston, G. E., Currier, E. A., Vanover, K. E., Harvey, S. C., Donohue, E., Hansen, H. C., Andersson, C. M., Spalding, T. A., Gibson, D. F., Krebs-Thomson, K., Powell, S. B., Geyer, M. A., Hacksell, U., and Brann, M. R. (2001) 5hydroxytryptamine $2 \mathrm{~A}$ receptor inverse agonists as antipsychotics. $J$. Pharmacol. Exp. Ther. 299 (1), 268-276.

(19) Nichols, D. E. (2012) Structure-activity relationships of serotonin 5-HT 2A agonists. WIREs Membr. Transp. Signaling 1, $559-579$.

(20) Schardl, C. L., Panaccione, D. G., and Tudzynski, P. (2006) Ergot alkaloids - biology and molecular biology. Alkaloids: Chem. Biol. $63,45-86$.

(21) Tfelt-Hansen, P., Saxena, P. R., Dahlöf, C., Pascual, J., Láinez, M., Henry, P., Diener, H., Schoenen, J., Ferrari, M. D., and Goadsby, P. J. (2000) Ergotamine in the acute treatment of migraine: a review and european consensus. Brain 123 (1), 9-18.

(22) Reichmann, H., Bilsing, A., Ehret, R., Greulich, W., Schulz, J. B, Schwartz, A., and Rascol, O. (2006) Ergoline and non-ergoline 
derivatives in the treatment of Parkinson's disease. J Neurol. 253 (4), 36-38.

(23) Colao, A., Abs, R., Bárcena, D. G., Chanson, P., Paulus, W., and Kleinberg, D. L. (2008) Pregnancy outcomes following cabergoline treatment: extended results from a 12 -year observational study. Clin. Endocrinol. 68 (1), 66-71.

(24) Glennon, R. A., Raghupathi, R. K., Bartyzel, P., Teitler, M., and Leonhardt, S. (1992) Binding of phenylalkylamine derivatives at 5$\mathrm{HT}_{1 \mathrm{C}}$ and $5-\mathrm{HT}_{2}$ serotonin receptors: evidence for a lack of selectivity. J. Med. Chem. 35, 734-740.

(25) Parker, M. A., Marona-Lewicka, D., Lucaites, V. L., Nelson, D. L., and Nichols, D. E. (1998) A novel (benzodifuranyl)aminoalkane with extremely potent activity at the $5-\mathrm{HT}_{2 \mathrm{~A}}$ receptor. J. Med. Chem. 41 (26), 5148-5149.

(26) McLean, T. H., Parrish, J. C., Braden, M. R., Marona-Lewicka, D., Gallardo-Godoy, A., and Nichols, D. E. (2006) 1-Aminomethylbenzocycloalkanes: conformationally restricted hallucinogenic phenethylamine analogues as functionally selective 5-HT2A receptor agonists. J. Med. Chem. 49 (19), 5794-5803.

(27) Nelson, D. L., Lucaites, V. L., Wainscott, D. B., and Glennon, R. A. (1999) Comparisons of hallucinogenic phenylisopropylamine binding affinities at cloned human 5-HT2A, -HT(2B) and 5-HT2C receptors. Naunyn-Schmiedeberg's Arch. Pharmacol. 359 (1), 1-6.

(28) Ho, B. T., Tansey, L. W., Balster, R. L., An, R., McIsaac, W. M., and Harris, R. T. (1970) Amphetamine analogs. II. Methylated phenethylamines. J. Med. Chem. 13 (1), 134-135.

(29) Heim, R. Synthese und Pharmakologie potenter 5-HT2ARezeptoragonisten mit N-2-Methoxybenzyl-Partialstruktur. Entwicklung eines neuen Struktur-Wirkungskonzepts. Ph.D. Thesis, Freie Universität Berlin, Berlin, Germany, 2003.

(30) Halberstadt, A. L., and Geyer, M. A. (2013) Effects of the hallucinogen 2,5-dimethoxy-4-iodophenethylamine (2C-I) and superpotent N-benzyl derivatives on the head twitch response. Neuropharmacology 77, 200-207.

(31) Juncosa, J. I., Jr., Hansen, M., Bonner, L. A., Cueva, J. P., Maglathlin, R., McCorvy, J. D., Marona-Lewicka, D., Lill, M. A., and Nichols, D. E. (2013) Extensive rigid analogue design maps the binding conformation of potent N-benzylphenethylamine 5-HT2A serotonin receptor agonist ligands. ACS Chem. Neurosci. 4 (1), 96109.

(32) Ettrup, A., Hansen, M., Santini, M. A., Paine, J., Gillings, N., Palner, M., Lehel, S., Herth, M. M., and Madsen, J. (2011) Radiosynthesis and in vivo evaluation of a series of substituted 11Cphenethylamines as 5-HT2A agonist PET tracers. Eur. J. Nucl. Med. Mol. Imaging 38 (4), 681-693.

(33) Ettrup, A., Holm, S. R., Hansen, M., Wasim, M., Santini, M. A., Palner, M., Madsen, J., Svarer, C., Kristensen, J. L., and Knudsen, G. M. (2013) Preclinical Safety Assessment of the 5-HT2A Receptor Agonist PET Radioligand $\left[{ }^{11} \mathrm{C}\right]$ Cimbi-36. Mol. Imaging Biol. 15 (4), 376-383.

(34) Blaazer, A. R., Smid, P., and Kruse, C. (2008) G.Structureactivity relationships of phenylalkylamines as agonist ligands for 5HT(2A) receptors. ChemMedChem 3 (9), 1299-1309.

(35) Isberg, V., Balle, T., Sander, T., Jorgensen, F., and Gloriam, D. (2011) G Protein- and Agonist-Bound Serotonin 5- $\mathrm{HT}_{2 \mathrm{~A}}$ Receptor Model Activated by Steered Molecular Dynamics Simulations. J. Chem. Inf. Model. 51, 315-325.

(36) Christiansen, B., Hansen, K. B., Wellendorph, P., and BräunerOsborne, H. (2007) Pharmacological characterization of mouse GPRC6A, an L- $\alpha$-amino acid receptor with ability to sense divalent cations. Br. J. Pharmacol. 150, 798-807.

(37) Brandish, P. E., Hill, L. A., Zheng, W., and Scolnick, E. M. (2003) Scintillation proximity assay of inositol phosphates in cell extracts: high-throughput measurement of G-protein-coupled receptor activation. Anal. Biochem. 313 (2), 311-318. 